Vol. 2, No. 1, 2020

https://doi.org/10.23939/jtbp2020.01.051

Orest Voznyak, Mariana Kasynets, Khrystyna Kozak, Iryna Sukholova, Oleksandr Dovbush

\title{
THERMAL MODERNIZATION OF HEATING SYSTEM BY USING THE SOLAR ROOF
}

\author{
Department of Heat and Gas Supply and Ventilation, \\ Lviv Polytechnic National University \\ orest.voznyak@i.ua
}

(C) Voznyak O., Kasynets M., Kozak Kh., Sukholova I., Dovbush O., 2020

An important priority of Ukraine's economic policy is the careful use of energy. The country has a broad-based energy efficiency policy, and energy efficiency is complex, covering both the legislative framework and technical innovations. One of the effective ways to reduce energy costs for the needs of the national economy is to carry out thermal modernization of the heating system. In this article economic indicators of thermal sanitary measures during reconstruction of the heating system of the object are given. In the reconstruction of the heating system, the following thermal renewal measures were adopted for comparison: installation of the solar roof, reconstruction of the heating system and installation of the heating air solar system. The purpose of this work is to establish the economic indicators of the thermal renovation measures in the reconstruction of the heating system of an apartment building using a solar roof at the different values of discount index. The use of modern methods of evaluating the cost-effectiveness of thermal modernization is taken into account in the latest concept of economic calculations, in particular the recommendation of United Nations Industrial Development Organization. Energy audit of the heating system was carried out taking into account the different values of discount index $r$. There were optimized the thermal renewal variants taking into account the different values of discount index was carried out. Using of the solar roof gives a possibility to design of effective energy-saving heating systems in the buildings. Solar air heating system has a high value of the simple payback time, but it is useful as aggregate energy saving variant and provides economic effect.

Key words: energy saving, solar roof, solar air heating system, thermal renewal measurements, energy audit, solar panel.

\section{Introduction}

Nowadays, the issues of energy saving, energy accounting and cost management are extremely topical. In the face of an acute economic crisis, careful use of energy is an important priority of Ukraine's economic policy. Today, as a priority, a large-scale energy-saving policy is being implemented in our country. Energy-saving tasks in Ukraine are complex and cover aspects of both external heat supply and internal engineering systems of buildings (heating, ventilation and air conditioning), as well as the legislative framework and technical innovation. A lot of energy is spent on creating a microclimate in industrial and residential premises.

There is no doubt, that the energy costs for the needs of the heating system must also be reduced as a result of thermal modernization. To achieve the maximum effect, it is necessary to determine the economically feasible level of heat protection of the heating systems, which should be optimal both in thermal and economic terms. The choice of energy-efficient operating conditions for existing heating systems is often made using the UNIDO technique. 


\section{Target of this article}

This article is intended for establishing of the economic indicators of the thermal renovation measures in the reconstruction of the heating system of an apartment building using a solar roof at the different values of discount index.

\section{Techniques used}

One of the energy-efficient ways to heat high rooms is to use systems with infrared heaters (Mysak et al., 2014; Voznyak \& Shapoval, 2010) that allow purposeful partial heating of different areas of the production room. To reduce heat losses in heat supply systems, it is advisable to insulate the fittings and shut-off valves (Voznyak et al., 2003).

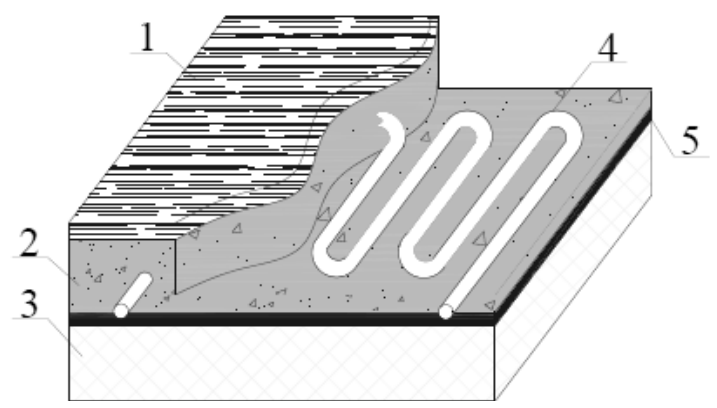

Fig. 1. Construction of the solar panel:

1 -protective coating; 2 - heat conducting layer; 3 -thermal insulation layer; 4 - pipeline for supply and removal of heat carrier; 5 - heat reflective screen

In the reconstruction of heating systems the thermal renovation (energy-saving) measures should be used (Voznyak et al., 2017; Zhelykh et al., 2019; Chen, 2011; Saleh, 2012). There are worthy of attention: installation of a solar roof, reconstruction of the heating system, installation of a solar air heating system (Summers, 2010; Mendaza, 2014; Fatah et al., 2015; Ajam et al., 2005).

On the basis of the theoretical and experimental research the energy saving design of the solar roof was developed (Fig. 1).

Technical solutions is proposed to improve the thermal performance of the solar roof (Fig. 1).

As a thermal barrier, a solar panel was used (Fig. 2), consisting of a protective coating 1, which serves as a water proofing and absorption layer and islocatedon a heat-conducting layer 2 , which acts as a heat energy accumulator, which houses corrugated pipelines 4 for supply and removing the coolant, the thermal insulation layer 3 to protect the floor slab from overheating, which is located under the heat-conducting layer, which houses the heat-reflecting screen 5 .

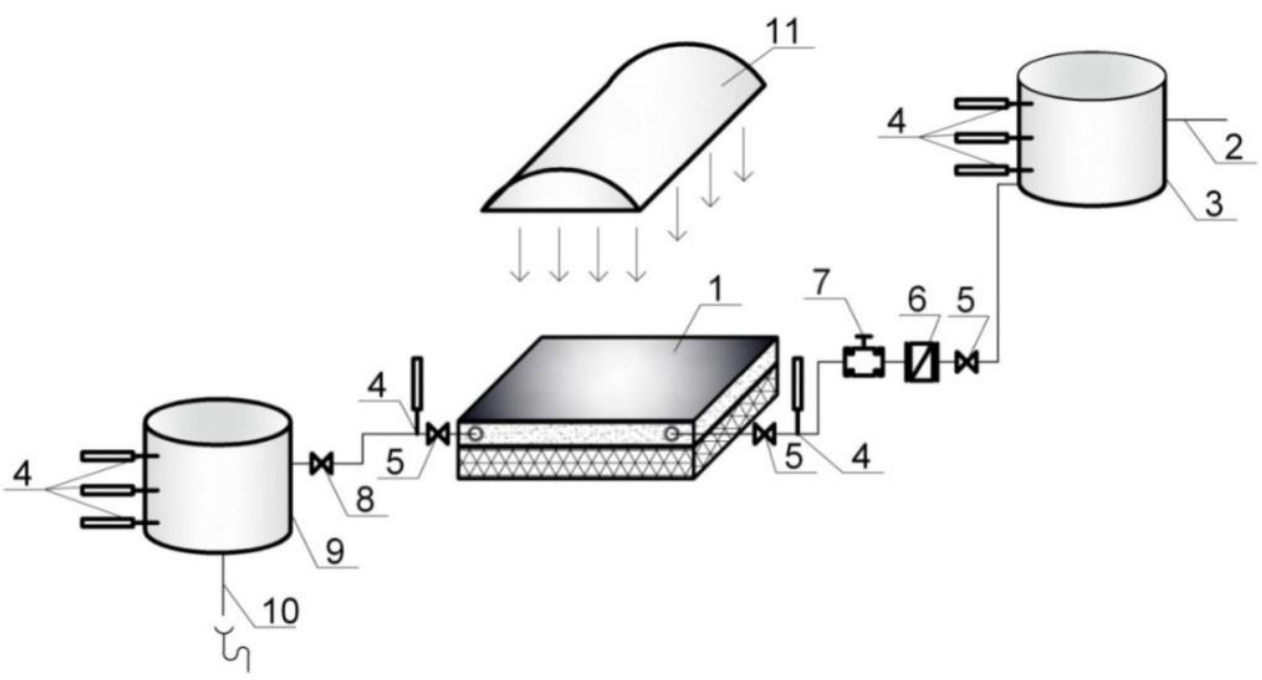

Fig. 2. Scheme of the experimental setup:

1 - solar panel; 2 (8) - pipeline of cold (heated) coolant; 3 (9) - tank of cold (heated) coolant; 4 - thermal sensor (resistance thermocouples); 5 - shut-off valves; 6 -flowmeter; 7 - balancing valve; 10 - drainage pipeline; 11 - thermal emitter. 
The installation consisted of a solar panel, a storage tank, shut-off valves, pipelines and a flow meter.

On this basis, a heating system with developed solar roof was proposed (Fig. 3). The developed structure can be installed on the roof of the building or installed in the roof.

An important step is to choose the method of placement of the phases of the transientheat storage material. In Fig. 3 it is shown an arrangement of heat storage with a saturated solution of Glauber salt in the air duct.

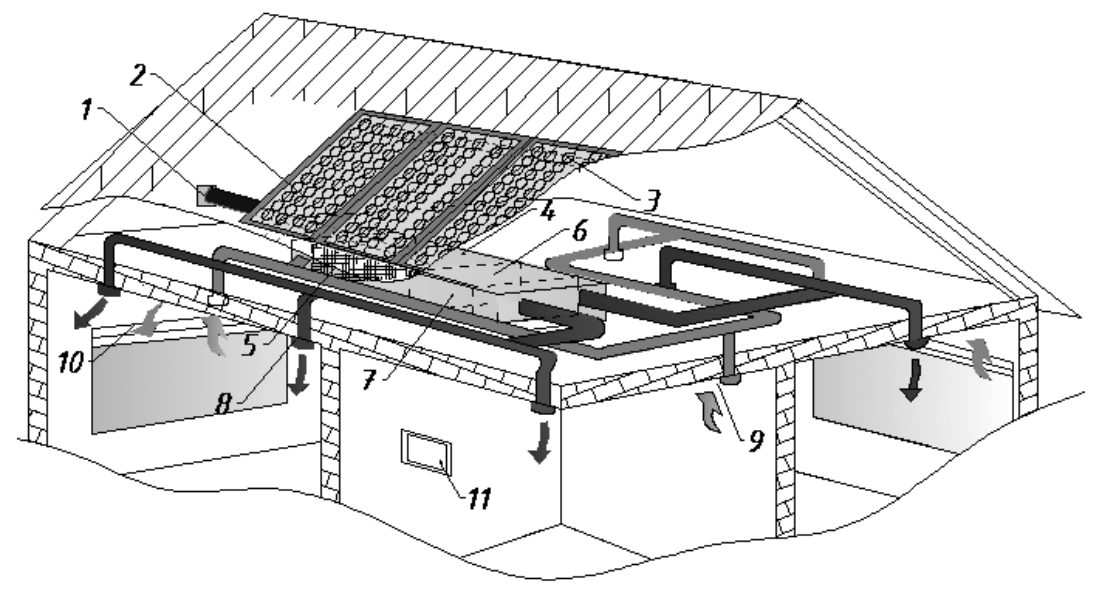

$a$

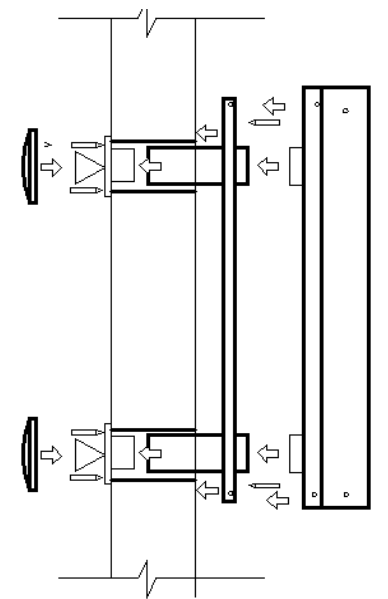

$b$

Fig. 3 Schemes of the HASS room with a phase-transition heat accumulator and solar collectors:

a) in the construction of the roof of the house; b) on the wall of the house;

1 -fresh air intake duct; 2 - air solar collector; 3 - the supply air duct; 4 - the main air duct with the accumulation covering; 5 - air filter; 6 -channel electric heater; 7 - fan; 8 -air distribution grid; 9 - air intake grate; 10 - apartment for natural ventilation; 11 - control unit

Therefore, thermo-modernization of the heating system is an effective way of reducing energy consumption for heat supply (Alkilani et al., 2011; Charvat et al., 2011; Zhao et al., 2011; Charvat et al., 2013). At the same time an important role is played by the technical and economic evaluation of the effectiveness of the measures. The use of modern methods of evaluating the cost-effectiveness of thermomodernization is taken into account in the latest concept of economic cal culations, in particular the recommendation of UNIDO (United Nations Industrial Development Organization) (Voznyak et al., 2017; Voznyak et al., 2003). In this regard, it is advisable to use terminology, symbols and key economic characteristics according to (Voznyak et al., 2019; Kharsef, 2012; Kim, 2001).

Energy audit of the heating system was carried out taking into account the different values of discount index $r$. This value depends on economical situation in Ukraine; it was $r=0.18$ in 2019 and $r=0.11$ in 2020 .

Thus, an optimal variant and its economic characteristics were obtained by the following order:

1. Calculation of annual energy consumption for the needs of heating system $Q_{0}, \mathrm{GJ} / \mathrm{year}$ and this option is considered as basic.

2. Thermal renewal measures are chosen:

2.1 Installation of the solar roof.

2.2 Reconstruction of the heating system.

2.3 Installing of solar air heating system.

3. Calculating energy efficiency $\Delta Q_{i}$ for each thermal renewal measure: $\Delta Q_{i}=Q_{o}-Q_{i}$, and hence annual savings $K_{i}, \mathrm{UAH} /$ year.

$$
K_{i}=\Delta Q_{i} \cdot P_{x}
$$


Obtained results are in Table 1.

Table 1

Characteristics of energy saving measures

\begin{tabular}{|c|l|c|c|c|c|}
\hline № & \multicolumn{1}{|c|}{ Measures } & $\begin{array}{c}\text { Energy costs for } \\
\text { the basic option } \\
Q_{o} \\
\text { GJ/year }\end{array}$ & $\begin{array}{c}\text { After the change } \\
Q_{i} \\
\text { GJ/year }\end{array}$ & $\begin{array}{c}\text { Energy saving } \\
\Delta Q_{i} \\
\Delta Q_{i}=Q_{o}-Q_{i} \\
\text { GJ/year }\end{array}$ & $\begin{array}{c}\text { Savings money } \\
K_{i} \\
K_{i}=\Delta Q_{i} P_{x,} \\
\text { UAH/year }\end{array}$ \\
\hline \hline 1 & 80.5 & 44.3 & 36.2 & 11946 \\
\hline 2 & $\begin{array}{l}\text { Installation of the solar roof } \\
\text { system }\end{array}$ & 80.5 & 70.5 & 10.0 & 3300 \\
\hline 3 & $\begin{array}{l}\text { Installing of the solar air heating } \\
\text { system. }\end{array}$ & 80.5 & 59.2 & 21.3 & 7029 \\
\hline
\end{tabular}

4. Capitalization of investment costs $I_{i}$ and work on each thermal renewal measure (Table 2).

5. Determination of indicators of each thermal renewal measure: $S P B T_{i}$, and $N P V R_{i}$ at the different values of discount index: $r=0.18$ (Ukraine, 2019) and $r=0.11$ (Ukraine, 2020) (Table 2).

Table 2

Economic indicators of the thermal renewal measures.

\begin{tabular}{|c|l|c|c|c|c|c|}
\hline \multirow{2}{*}{$№$} & \multicolumn{1}{|c|}{ Measures } & $I_{i}$ & $\mathrm{~K}_{\mathrm{i}}^{\prime}$ & $S P B T_{\mathrm{i}}$ & $\begin{array}{c}N P V R_{\mathrm{i}} \\
(r=0.18)\end{array}$ & $\begin{array}{c}N P V R_{\mathrm{i}} \\
(r=0.11)\end{array}$ \\
\cline { 2 - 7 } & $\mathrm{UAH}$ & $\mathrm{UAH} / \mathrm{year}$ & year & $\mathrm{UAH}$ & $\mathrm{UAH}$ \\
\hline \hline 1 & Installation of the solar roof & 72000 & 11946 & 6.0 & +6645 & +33224 \\
\hline 2 & $\begin{array}{l}\text { Reconstruction of the heating } \\
\text { system }\end{array}$ & 34000 & 3300 & 10.3 & +2509 & +12543 \\
\hline 3 & $\begin{array}{l}\text { Installing of solar air heating } \\
\text { system }\end{array}$ & 104000 & 7029 & 14.8 & +3592 & +17963 \\
\hline
\end{tabular}

6. Realization of optimization for getting of maximal economic effect (Table 3).

It should be noted that Table 3 includes two rows with the different values of discount index: $r=0.18$ (Ukraine, 2019) and $r=0.11$ (Ukraine, 2020). It is interesting to compare economical parameters at these conditions.

Table 3

Optimization of options for getting of maximal economic effect according to paragraph 6

\begin{tabular}{|c|l|c|c|c|}
\hline \multirow{2}{*}{ № } & \multicolumn{1}{|c|}{ Measures } & \multicolumn{2}{c|}{ Variants } \\
\cline { 3 - 4 } & & $I$ & $I I$ & III \\
\hline \hline 1 & Installation of the solar roof & + & + & + \\
\hline 2 & Reconstruction of the heating system & & + & + \\
\hline 3 & Installing of solar air heating system. & & & + \\
\hline & Indexes & & & \\
\hline 1 & InvestmentexpensesI (UAH) & 12000 & 106000 & 210000 \\
\hline 2 & Annualsavings $K$ (UAH) & 6.0 & 7.0 & 22275 \\
\hline 3 & Simple time of returning expenses- SPBT (year) & +6645 & +11226 & +12285 \\
\hline 4 & Net Present Value Ratio - NPVR( $r=0.18)(\mathrm{UAH})$ & +33224 & +56132 & +61423 \\
\hline 5 & Net Present Value Ratio - NPVR $r=0.11)(\mathrm{UAH})$ & +3324 & \\
\hline
\end{tabular}


Optimization was carried out according to order (Zhelykh et al., 2019). It should be noted, that lower value of the discount index $r$ results in to better situation concerning Net Present Value Ratio.

So, we have optimized the thermal renewal variant taking into account the data of p.6 and compile Table 3 ordered from the first thermal renewal measure"'Installation of the solar roof", which has minimal parameter $S P B T_{1}$, until the third one "Installing of solar air heating system" with a maximum $S P B T_{3}$.

We can assert, that the maximum economic effect is in the case of the simultaneous application of three thermal renewal measures (Table 3). It should be noted that the optimization carried out is complete and the different values of discount index were taking into account. The specific profit from the realization of energy-saving technologies during the period of their operation is over 60 thousands UAH.

\section{Conclusions}

1. Optimization of thermal renewal variants taking into account the different values of discount index was carried out.

2. Using the solar roof gives a possibility to design of effective energy-saving heating systems in the buildings.

3. Solar air heating system has a high value of SPBT, but it is useful as aggregate energy saving variant and provides economic effect.

\section{References}

Mysak, Y., Voznyak, O., Datsko, O., \& Shapoval, S. (2014). Solar energetic. Theory and practice. Lviv: NULP (in Ukrainian).

Voznyak, O. T., \& Shapoval, S. P. (2010). Efficiency of flat solar collector at different intensities and corners of the fall of the heat flow. Journal of the Association of Energy Efficient Technology Engineers of Ukraine: scientific-technical magazine "New Topic", 3(26), 32-34 (in Ukrainian).

Voznyak, O. T., Sukholova, I. Y., Savchenko, O. O., \& Dovbush, O. M. (2017). Thermal modernization of the air-conditioning system of industrial premises. Bulletin of the Odessa State Academy of Civil Engineering and Architecture. Issue 68, 114-120 (in Ukrainian).

Voznyak, O. T., Yurkevych, Yu. S. \& Zhelykh, V. M. (2003). Theoretical preconditions for optimization of combined thermal energetics during energy audit of the house, Proc. of Lviv Polytechnic National University: Heat Power Engineering. Environmental Engineering. Automation, No. 476, 140- 145 (in Ukrainian).

Zhelykh, V., Voznyak, O., Kozak, Kh., Dovbush, O., \& Kasynets, M. (2019). Civil buildings heating system thermal renewal. Proc. of Lviv Polytechnic National University: The theory and building practice, No1(2)2019, 7-13. https://doi.org/10.23939/jtbp2019.02.007

Ahmad M. Saleh (2012). Modeling of flat-plate solar collector operation in transient states. Purdue University, Fort Wayne, pp. 73.

Edward K. Summers (2010). High efficiency solar air heaters with novel built-in heat storage for use in a humidification-dehumidification desalination cycle. Massachusetts Institute of Technology, pp. 135.

Joseba M. Mendaza (2014). Solar Collectors for Air Heating Profitability Analysis. University of Gavle, pp. 77.

Fatah. O., Ghuol A. L., Sopian K., Shahrir Abdullah, Mohammed Al-Ghoul \& Ali Whaad (2015). Heat Transfer Enhancement Techniques for Solar Air Collector Heater: Review. Modern Applied Science, 9(9), 20-34.

Ajam H., Farahat S., \& Sarhaddi F. (2005). Exergetic Optimization of Solar Air Heaters and Comparison with Energy Analysis. Int. Journal of Thermodynamics, 5(4), 183-190.

Min Chan Kim (2001). The Oncet of Natural Convection and Heat Transfer Correlation in Horizontal Fluid Layer Heated Uniformly from Below. KSME International Journal, 15(10), 1451-1460.

Kharsef M. (2012). Energy Balance of Solar Collector. Lulela University of Technology, pp. 27.

Julian Chen (2011). Physics of Solar Energy. JOHN WILEY \& SONS, INC, New Jersey, pp. 312.

Charvat P., Mauder T., \& Klimes L. (2011). A solar air collector with integrated latent heat thermal storage. The European Physical Journal Conferences 25, pp. 5.

Alkilani M. M., Sopian K., Alghoul M. A., Sohif M., \& Ruslan M.H. (2011). Review of solar air collectors with thermal storage units. Renewable and Sustainable Energy Reviews 15, 1476-1490. 
Zhao D. L., Li Y., Dai Y.J., \& Wang R. Z. (2011). Optimal study of a solar air heating system with pebble bed energy storage. Energy Conversion and Management 52, 2392-2400.

Charvat P., Pech O., \& Hejcik, J. (2013). Experimental investigations of the performance of a solar air collector with latent heat thermal storage integrated with the solar absorber. The European Physical Journal Conferences, pp. 4.

О. Т. Возняк, М. Є. Касинець, Х. Р. Козак, І. Є. Сухолова, О. М. Довбуш Національний університет “Львівська політехніка", кафедра теплогазопостачання і вентиляції

\title{
ТЕРМОМОДЕРНІЗАЦІЯ СИСТЕМИ ОПАЛЕННЯ 3 ВИКОРИСТАННЯМ ГЕЛІОПОКРІВЛІ
}

\author{
(C) Возняк О. Т., Касинець М. Є., Козак Х. Р., Сухолова І. С., Довбуш О. М., 2020
}

Важливим пріоритетним завданням економічної політики України є дбайливе використання енергоносіїв. У країні проводиться широкомасштабна політика енергоощадності, а завдання енергоощадності є комплексними та охоплюють як законодавчу базу, так і технічні інновації. Одним 3 ефективних способів зменшення енергозатрат на потреби народного господарства є проведення термомодернізація систем теплопостачання. Наведено економічні показники термореноваційних заходів при реконструкції системи опалення житлового будинку. Порівнювали такі термореноваційні заходи: встановлення геліопокрівлі, реконструкція системи опалення, встановлення системи сонячного повітряного опалення. Метою роботи є встановлення економічних показників заходів теплового оновлення при реконструкції системи опалення багатоквартирного будинку з використанням сонячної покрівлі за різних значень індексу знижок. Використання сучасних методів оцінювання економічної ефективності теплової модернізації враховується в новітній концепції економічних розрахунків, зокрема рекомендаціями Організації Об’єднаних Націй із промислового розвитку. Енергетичний аудит системи опалення проводили з урахуванням різних значень індексу знижок $\mathrm{r}$. Було оптимізовано варіанти теплового оновлення 3 урахуванням різних значень індексу знижок. Використання сонячної покрівлі дає можливість проектувати ефективні енергоощадні системи опалення в будинках. Сонячна система нагрівання повітря має високу цінність простого часу окупності, але вона корисна як сукупний варіант економії енергії та забезпечує економічний ефект.

Ключові слова: енергоощадність, геліопокрівля, система сонячного повітряного опалення, термореноваційні заходи, енергоаудит, сонячна панель. 